\title{
CONSERVATION OF HISTORICAL REINFORCED CONCRETE STRUCTURES
}

\section{ILDIKÓ BUCUR-HORVÁTH ${ }^{1}$, JÁCINT VIRÁG ${ }^{1 *}$}

\author{
Technical University of Cluj-Napoca \\ 15 C-tin Daicoviciu Street, 400020 Cluj-Napoca, Romania \\ e-mail: ilbucurro@yahoo.com, jacint.virag@dst.utcluj.ro (*corresponding author)
}

Keywords: Historical Reinforced Concrete Structure, Cupola, Hollow Block Slab

\begin{abstract}
During the 20th century, reinforced concrete brought historical structural systems back into modern times, transforming them into high-performance structures. Reflection on early reinforced concrete structures of two ancient structural systems, the dome and the girder, is presented through two Transylvanian monuments: the reinforced concrete cupola of the Hungarian Theater of Cluj, the earliest structure of this type, and the one-way hollow block slabs of Villa Tataru designed as a duet, by Gio Ponti and Elsie Lazar. Diagnosis and therapy of the hundred-year old, "new" historical structures are described. Uncovering these remarkable, but nearly unknown buildings, the paper intends to contribute to the understanding of cultural heritage and to raise public awareness towards the fundamental principle of UNESCO: "The cultural heritage of each is the cultural heritage of all".
\end{abstract}

\section{INTRODUCTION}

Part of European architectural heritage is built with reinforced concrete structures. The epoch of the reinforced concrete affirmation started in the $19^{\text {th }}$ century when large fields of its application opened. Due to its special qualities, there is a large competition in finding various forms of using reinforced concrete. During the $20^{\text {th }}$ century, reinforced concrete brought historical structural systems back into the modern times, making them high-performance structures. At the beginning of $20^{\text {th }}$ century, the state of knowledge of RC structures was far from a full understanding of the behavior of this new material and certain arbitrariness was present in the design [9].

The paper involves structural assessment for two historical reinforced concrete structures from Transylvania, to uncover their state-of-the-art. Large investigations have brought out a lot of interesting and useful structural elements. They will be extensively commented.

The spherical dome of (1909-1910) is the very first reinforced concrete cupola of large span, with basic ring, supported by masonry piles. The reinforced concrete shell is two-layered according to the antique Roman model in more ways than one. 


\section{THE FIRST LARGE-SPANNED REINFORCED CONCRETE CUPOLA}

Bridging large spans, the dome as structural form accompanies the whole history of architecture. The roots of the cupola building can be found in the ancient dwelling constructions. Archaeological discoveries have pointed out that the inhabitants of Jericho $\left(8^{\text {th }}\right.$ millennium BC) lived in circular houses covered with clay-brick cupolas. Curved and bound wood pieces, knitted reed, and clay were used in other cases and places. The fact that the Latin name of the cupola - domus - means dwelling cannot be a mere coincidence. Archaeological discoveries highlighted that the dome had also been used by the architects of antique Egypt and Mesopotamia. This tradition was continued by the Sassanid-Persian architecture. The cupola building was essentially improved by the Romans. Their domes were built of stone or/and "opus caementitium" (Roman concrete) cast in timber or stone shuttering. Thereupon, the cupola accompanied the entire series of architectural ages: Early Christian, Byzantine, Islamic, Roman, Gothic, Renaissance, Baroque, Neo-classical and modern architecture as well [1].

The "renaissance" of the domes is related to the discovery of the reinforced concrete. The concrete dome of St. Ursula parish church in Munich, built-in 1897, marks the beginning of concrete domes [2] and is a link between the traditional massive dome structures and modern thin shell construction.

The first modern domes mentioned by technical references were built in the first two decades of the $20^{\text {th }}$ century. In chronological order, the very first ones are the little cupolas of the Anatomical Institute of München (1905-1907) placed around a central space, by Max Littman

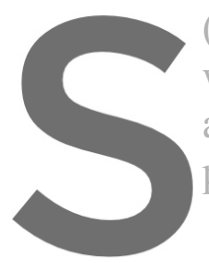
(It was demolished) a with a span of $65 \mathrm{~m}($ arches bound by horizontal professor Willy Gehler.
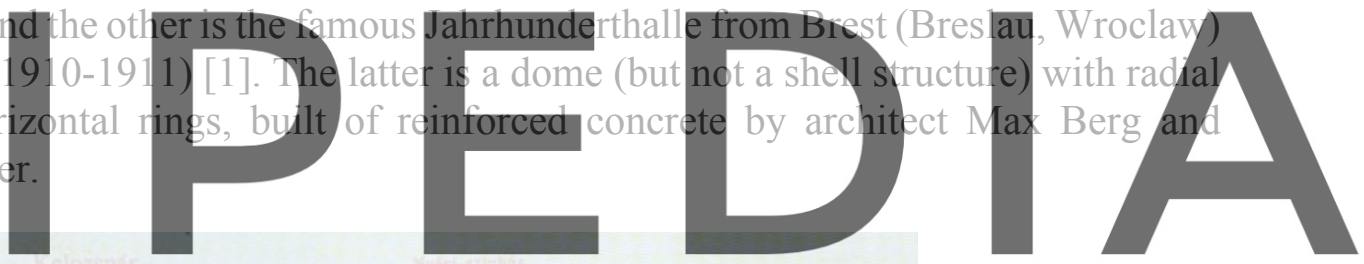

Register for free at https//www.scipedia.com to download the version without the watermark

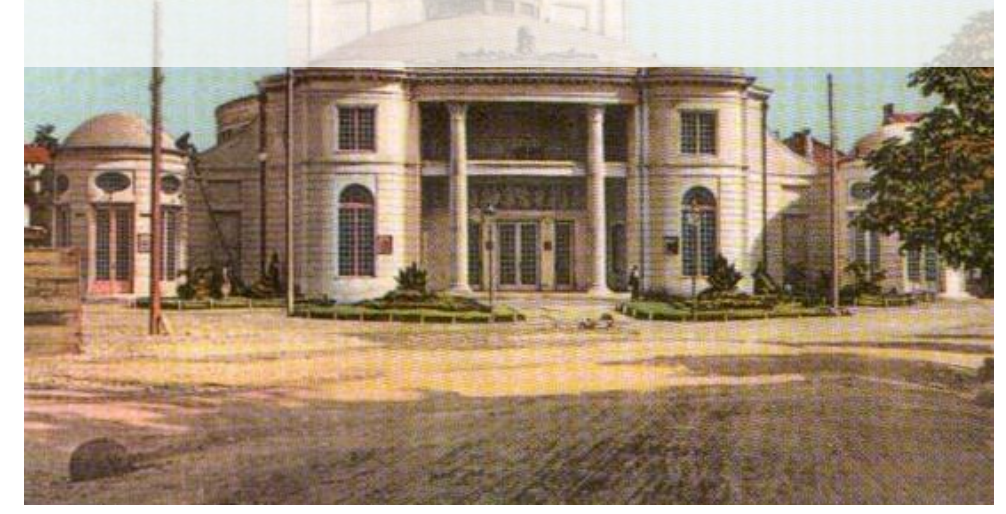

Figure 1: The original neoclassical building (postcard from 1914)

In Cluj-Napoca (Kolozsvár, Klausenburg) a similar early reinforced concrete cupola covers the central hall of the Hungarian Theatre and Opera house [3]. It is the very first large-spanned reinforced concrete cupola in the world. It features all characteristics of classic cupolas: it has 
an "opeion" and "tambour" at the top and a perimeter ring at the bottom which rest on vertical masonry pillars. The original form of the building is presented in Figure 1.

Documents prove that the building was designed in 1909 as a Summer Playhouse. It was intended for operetta, comedy performances, and for social events. The original project is preserved in the National Archives of Hungary and it is signed by the architects Frigyes Spiegel and Géza Márkus, from Budapest and by the constructor Alajos Réhling from Kolozsvár (Cluj) on the $25^{\text {th }}$ July 1909 (Figure 2). Reinforcement plans were approved by the engineer and professor Aladár Kovács Sebestyén. The diary news of the time confirms that the building was inaugurated on the $18^{\text {th }}$ of August 1910 [1].

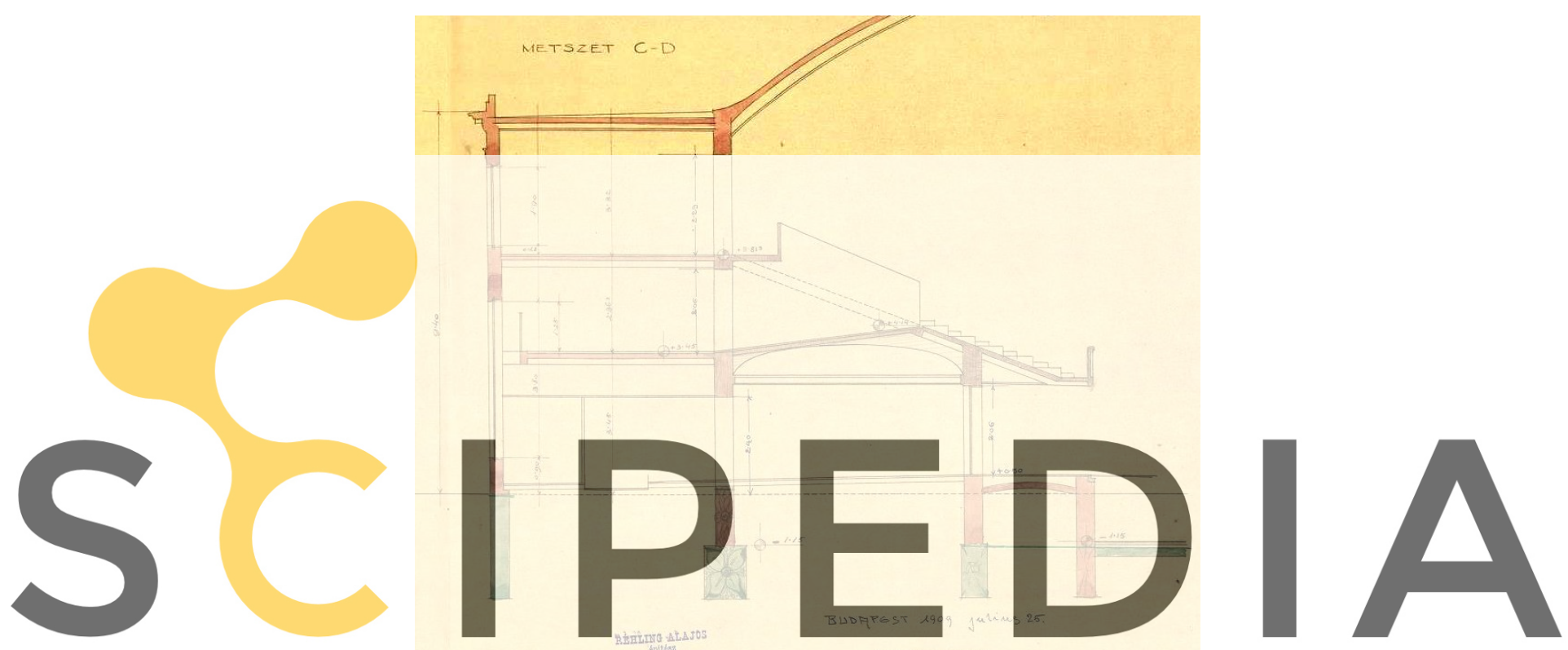

Register for free at https//www.scipedia.com to download the version without the watermark

Figure 2: Section plan with the authors signatures, original project from 1909, National Archives of Hungary

The whole building is composed of several blocks corresponding to a classic organization of the space for the required function (Figure 3). The main block is that of the public hall on a circular plan, covered with a spherical cupola. More than half of its perimeter is surrounded by a circular corridor, covered with a toric shell, also unique at that time. The stage building arises behind the main hall and continues with the storage and cloakrooms.

The spherical dome was designed and built with a $21.98 \mathrm{~m}$ radius of curvature, $27.72 \mathrm{~m}$ span, and $5.00 \mathrm{~m}$ rise and has been preserved to this day (Figure 4). There are two superposed thin shells: a $12 \mathrm{~cm}$ thick upper shell with its thickness slightly increasing towards the basic ring and below - at $25 \mathrm{~cm}$ - another shell with a constant thickness of $8 \mathrm{~cm}$, which supports the ornamental plastering of the ceiling. The two shells are connected to each other by steel wires of $2 \mathrm{~mm}$ in diameter placed every $40 \mathrm{~cm}$ apart. On the top of the cupola, there is a tambour of reinforced concrete with a wall thickness of $16 \mathrm{~cm}, 6.00 \mathrm{~m}$ in diameter and $1.30 \mathrm{~m}$ in height. 


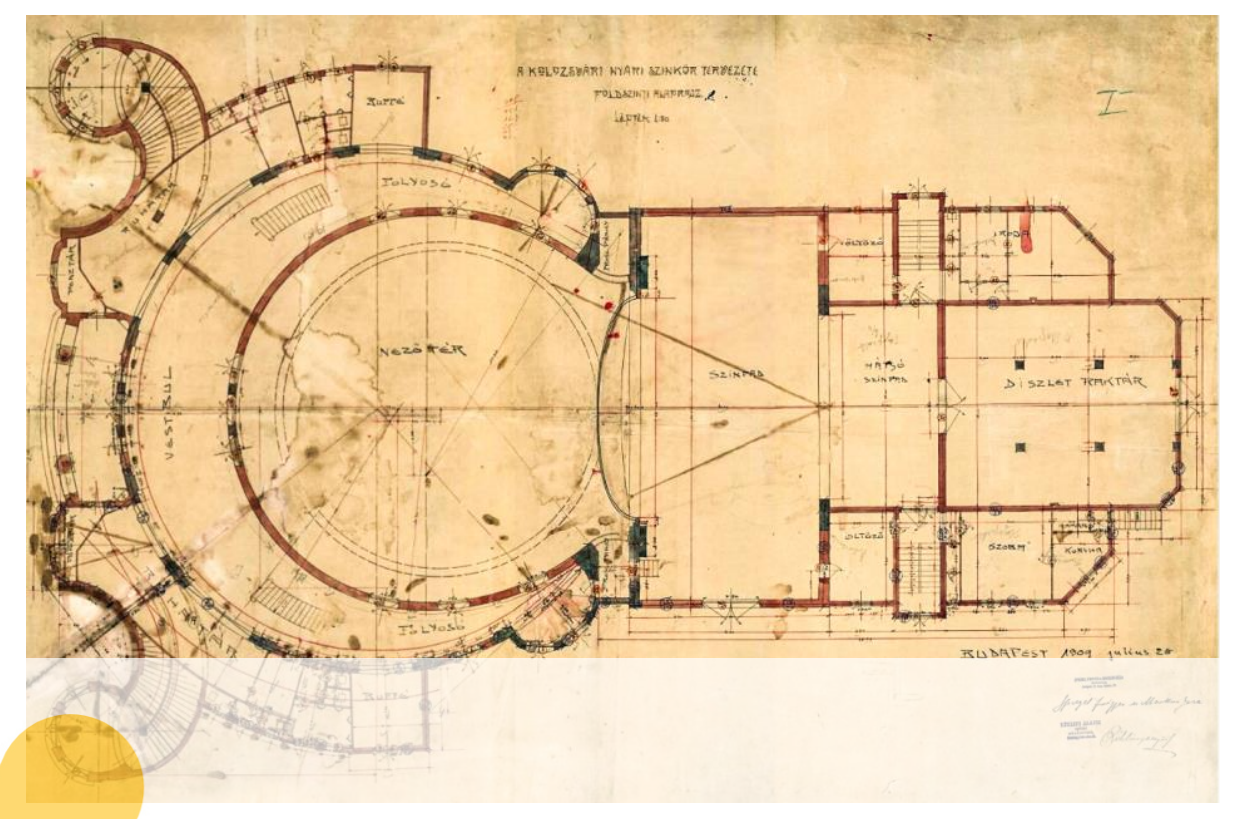

Figure 3: Ground floor plan, original project from 1909, National Archives of Hungary

The tambour is covered with a small reinforced concrete cupola of $60 \mathrm{~cm}$ rise. Under this small cupola, the dome has a central opening with a diameter of $2.00 \mathrm{~m}$. The largecandelabrum is suspended through this opening and is sustained by a special mechanism. The rei the main cupola (identified in the region of the central opening) consists of two mes
bars of $8 / 200 \mathrm{~mm}$ in meridian and $8 / 300 \mathrm{~mm}$ in circular direction in the $\mathbf{u p p e r}$ sh same mesh, as well as an additional Rabitz net, in the lower shell. $S$

Register for free at https//www.scipedia.com to download the version without the watermark

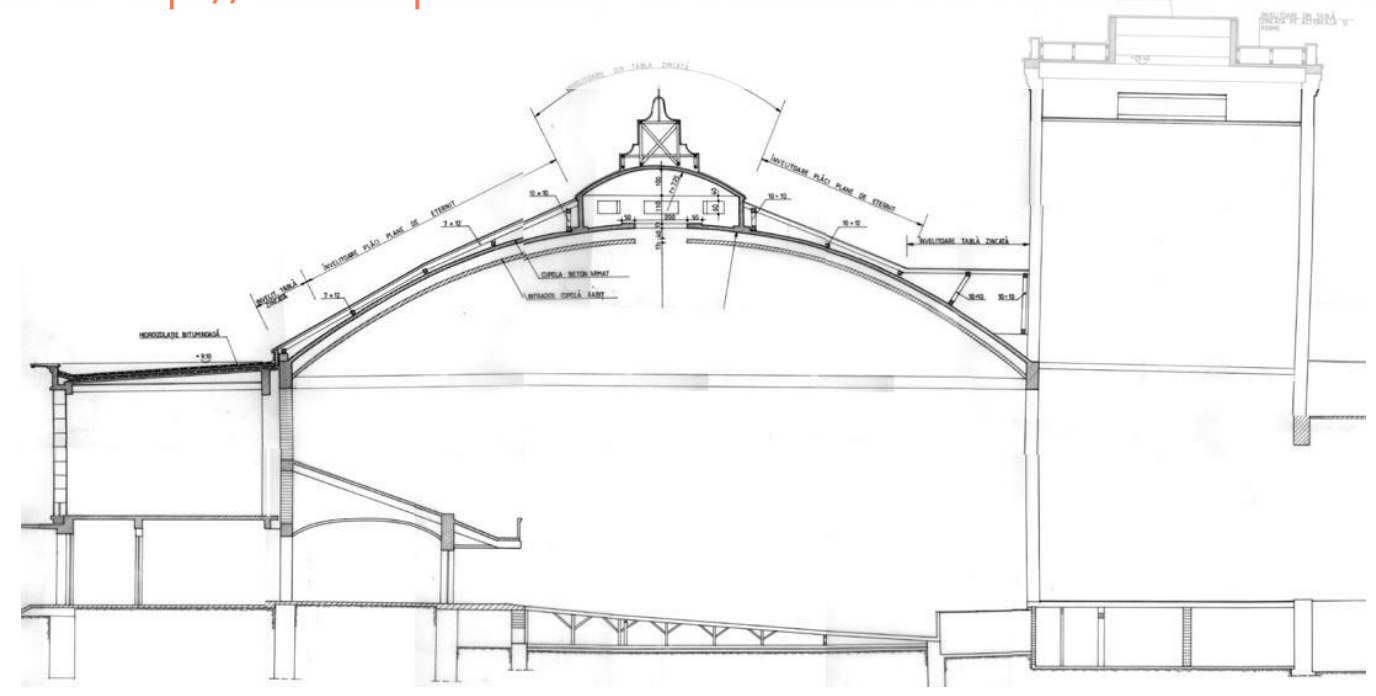

Figure 4: Cross-section: timber structure over the cupola, intervention project from 1959 
The two-layered cupola lies on a basic ring with a cross-section of $50 \times 110 \mathrm{~cm}$ along the perimeter excepting the portion neighboring the stage side $(60 \times 160 \mathrm{~cm})$. Very ingeniously, the base ring is connected to the surrounding constructive elements, mainly slabs, at the same level, which block the lateral displacement, arising due to the action of the normal meridian forces on the edges of the shell. The cupola is supported by vertical pilasters of masonry placed under the perimeter ring. Research performed on the cupola revealed a well-balanced structure. In 1959, due to functional reasons, the old staircases were demolished and a new, larger entrance hall with large interior staircases was added. The two lateral pavilions were also demolished. Thus, the neoclassical facade disappeared. The external look of the cupola was also influenced: a timber structure supporting the covering was placed over the reinforced concrete cupola, raising the external profile line and hiding the central tambour. Due to these changes, the building, unfortunately, lost its original neoclassic personality [4] (Figure 5).

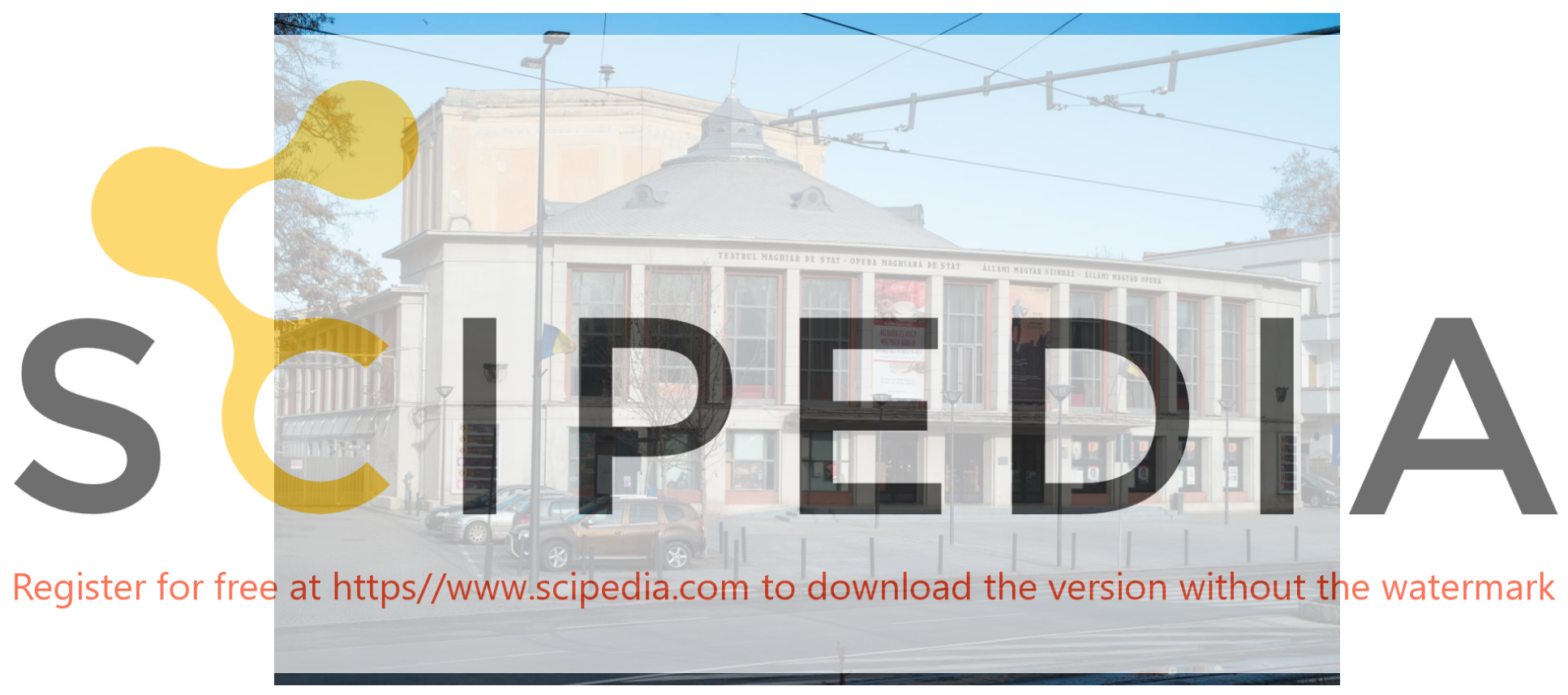

Figure 5: Street view 2020 - Hungarian Theathre Cluj, Karoly Miklos photographer

Fortunately, the main block comprising the public hall and the corridor under the dress circle, covered by reinforced concrete shells, remained unchanged. The building has been used continuously since it was built. No intervention was made on the reinforced concrete dome. No structural deficiencies were observed. However, safety reasons would require a new investigation.

The large investigation made on the building was very helpful for the two-layered cupola. It is interesting to remark that, while the upper shell surface is regular and smooth, the superior face of the lower shell is rough and unprocessed. The two shells are connected by steel wires, as mentioned above. Actually, the mesh of reinforcement of the lower shell is connected by the wires included in the upper shell. However, the inferior cupola is not suspended from the superior one. That is proved by the fact that most of the connecting wires are not straightened. All these facts make possible the assumption about the way the cupola was erected. In this 
order:

(1) First, the upper shell was cast in a shuttering sustained by a general scaffolding. The connecting wires are included in this reinforced upper layer.

(2) The reinforcing mesh of the lower shell was suspended on the upper shell by the connecting wires, and a Rabitz net was fixed on its lower face. The casting of the lower shell was not possible otherwise than horizontal strip by horizontal strip beginning from the basic ring, performed by plastering (according to the antique Roman model). In this way, the lower shell became self-bearing, supporting its own weight as well as the ornaments of the ceiling.

During the investigations in several points near the central opening of the cupola, the measured compressive cylinder strength was between $26-30 \mathrm{~N} / \mathrm{mm}^{2}$. The concrete of the shell was well compacted. No damages were observed.

The characteristics of the reinforcing steel are: the grade corresponds to the characteristic yield stress of $360 \mathrm{~N} / \mathrm{mm}^{2}$, high ductility, and 8-10 $\mathrm{mm}$ size plain smooth bars. Mezzanine floors are made of reinforced concrete, of $22 \mathrm{~cm}$ depth by $6 \mathrm{~cm}$ width ribs, spaced at $27 \mathrm{~cm}$ and a $6 \mathrm{~cm}$ topping, covering spans up to 6,0 $\mathrm{m}$. One-way hollow block slabs were formed by placing the blocks on a wooden formwork and concreting the reinforced ribs.

\section{ONE WAY HOLLOW BLOCK SLAB}

The second structural form examined was the ribbed slab. The beam, as one of the most intuitive bending structures, has been widely used from ancient times, even in the absence of beam theory and calculus. Adjoining beams, one-way slabs were formed. With the development of reinforced concrete becomes a convenient s the construction proces optimal shape infill blocks fostered the spread are used to reduce the weight of slab, offering e-way slabs were formed. With the development
late $19^{\text {th }}$ and early $20^{\text {th }}$ century, the ribbed slab
use until today. To reduce formwork and case
troduced between the ribs. Mass fabrication of
f hollow block slab construction. Voided blocks
casy installation with minimal formwork. Such slabs were designed in Gio Ponti's office, to be built in the villa of professor Tataru, in Cluj-

Register fakffee at https//www.scipedia.com to download the version without the watermark

Villa Tataru, built in 1938, is peaceful and modest: it was meant to be just a home, designed for the comfort of daily life, for a happy and fulfilled life [5].

The restoration process has recently started. Despite interventions during the lifetime of the building, the main form and structure has been preserved. Today, however, it requires rehabilitation. Aiming at minimal intervention, intensive structural research was performed under the authors' supervision. Complete documentation has been done, concerning history, geometry, materials, construction techniques, and structural works. The slab over the salon required special attention because excessive deformation has been observed at the midspan. Qualitative analysis of reinforced concrete slab was limited, because of the hollow block system, used as formwork, covers the bottom of the slab (Figure 7). In order to decide the structural intervention, the causes of damage had to be first determined [6]. Consequently, an investigation was carried out on the structure. The depth of reinforced concrete slab was found to be $24 \mathrm{~cm}$, made of $8 \mathrm{~cm}$ width ribs at a spacing of $24 \mathrm{~cm}$ and $7.5 \mathrm{~cm}$ thick topping. 


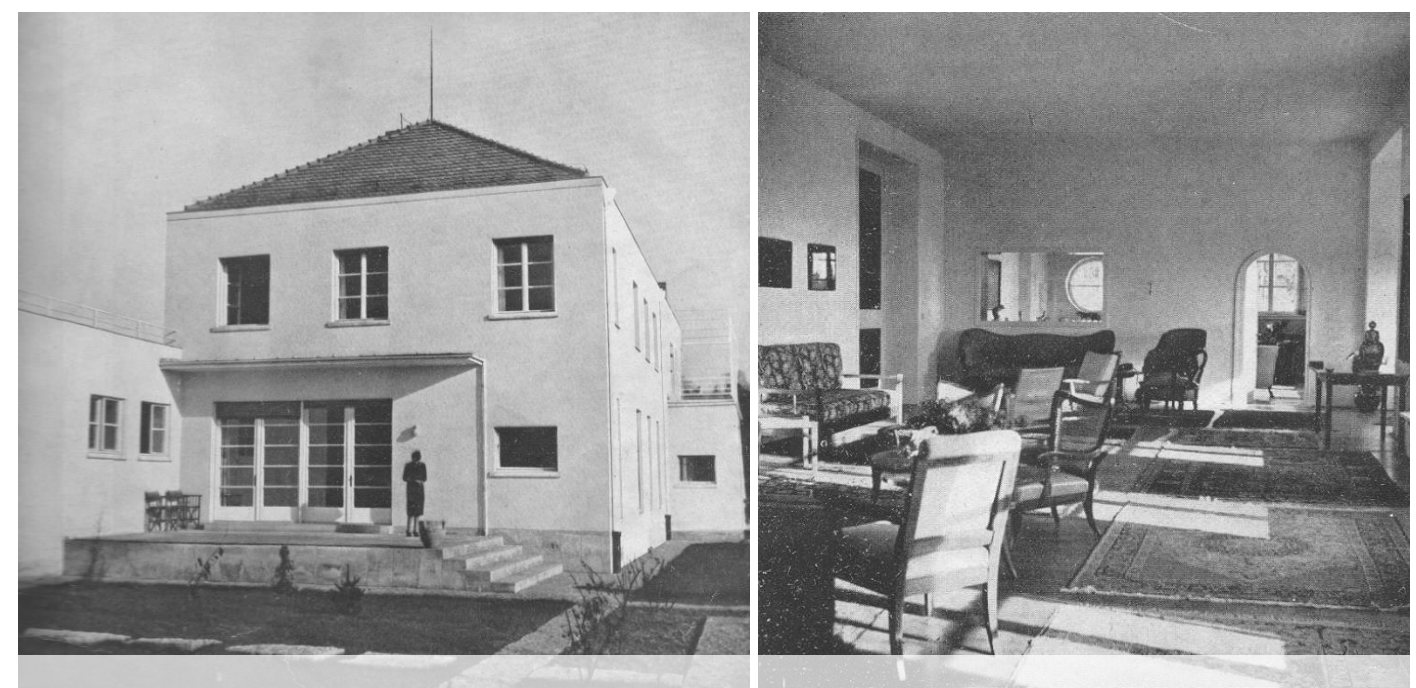

Figure 6: Original building: West side and salon [5]

The quantitative approach was based on material and structural tests, monitoring, and structural analysis. The compressive strength of the concrete was established by testing of cores and prism cut from the slab, while the modulus of elasticity was established by testing the prisms. The average cylinder strength of concrete is $28,2 \mathrm{~N} / \mathrm{mm}^{2}$, for the top surface and lower strength on the ribs, due results can be conside coincide, for deflection The corresponding conction number of samples (1) is C25/30

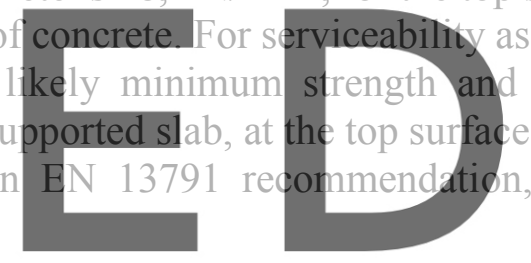

$f_{c k}=f_{m}-k$

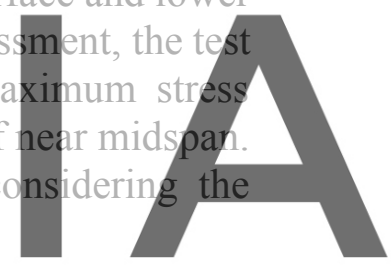

(1)

Register for free at https//www.scipedia.com to download the version without the watermark

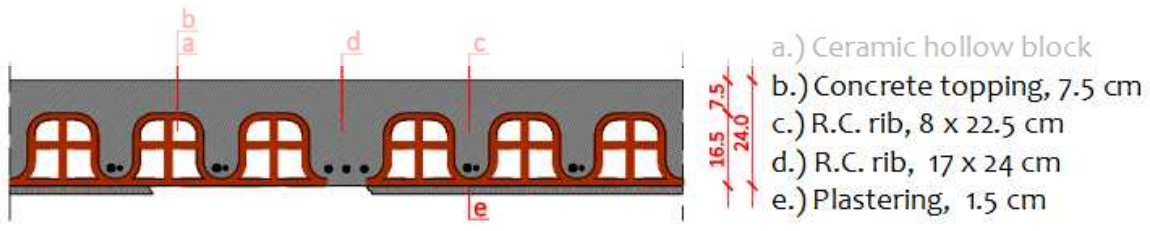

Figure 7: Cross-section of hollow block slab above salon

The value obtained for the Secant Modulus of Elasticity of slab concrete is $22.630 \mathrm{GPa}$. Rebar properties were determined on extracted samples, corresponding to a steel grade of S235C. Bottom reinforcement of thinner ribs are made of a $10-$ and $18-\mathrm{mm}$ rebar, while the wider ribs (under partition walls) are reinforced with 3 pieces of $16 \mathrm{~mm}$ rebar. Concrete cover is $20 \mathrm{~mm}$.

Uncertainty regarding hidden ribs and a deflection of $50 \mathrm{~mm}$ near the midspan of ribs indicated a need for load testing and monitoring, with the main purpose of proving structural adequacy, assuming that deflection is from the construction stage, due to a possible formwork settlement. A non-destructive static load test was carried out on the critical location, monitoring 
the structural behavior, especially deflection for demonstration of serviceability.

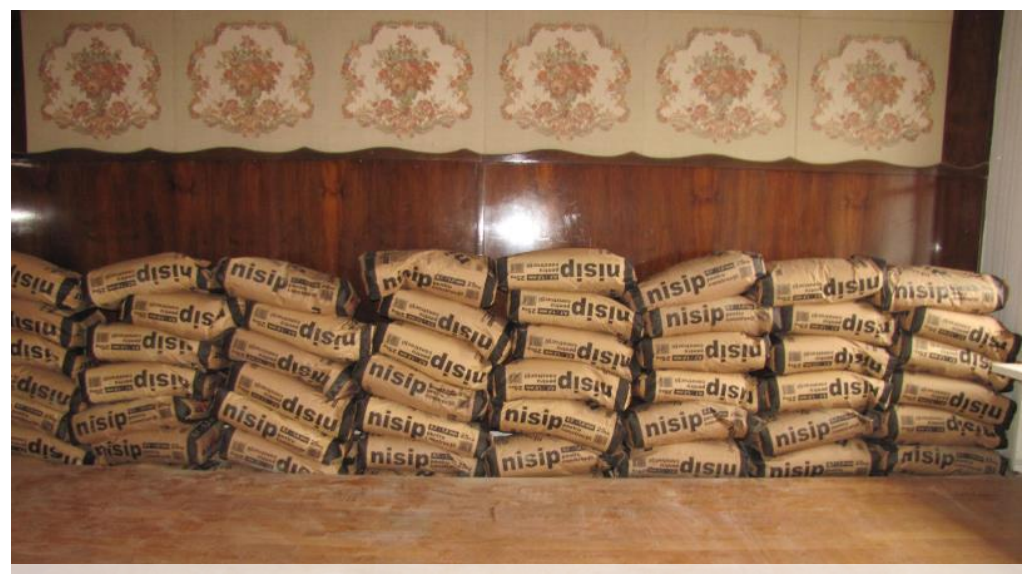

Figure 8: Sandbags as test loads added over the slab

The maximum load of $3.5 \mathrm{kN} / \mathrm{m}$ was applied incrementally using sand bags (Figure 8). The problem of ensuring that one way spanning members under test are actually subjected to the assumed test load is often difficult, due to load sharing effects. Isolation of ribs subjected to test from the surrounding structure would be preferred but saw cutting of monument is not acceptable.

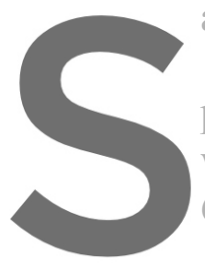

Measurement of de performance. With no $6.5 \mathrm{~mm}(2)$.
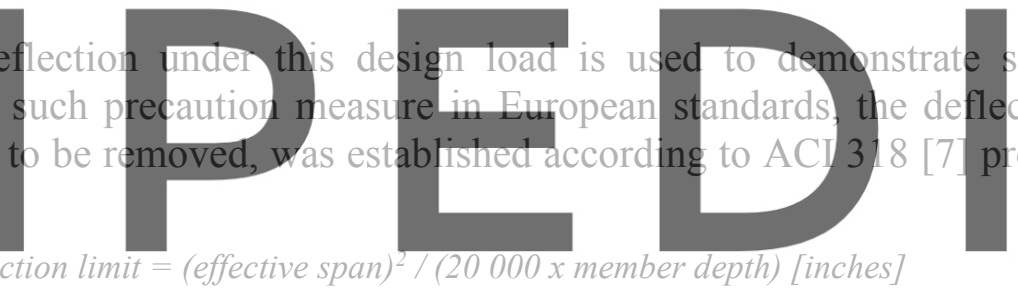

$$
\text { deflection limit }=(\text { effective span })^{2} /(20000 x \text { member depth }) \text { [inches] }
$$

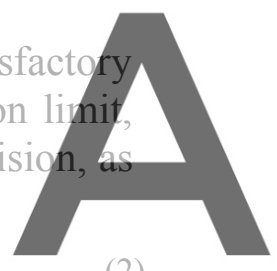

(2)

Register for free at https//www.scipedia.com to download the version without the watermark

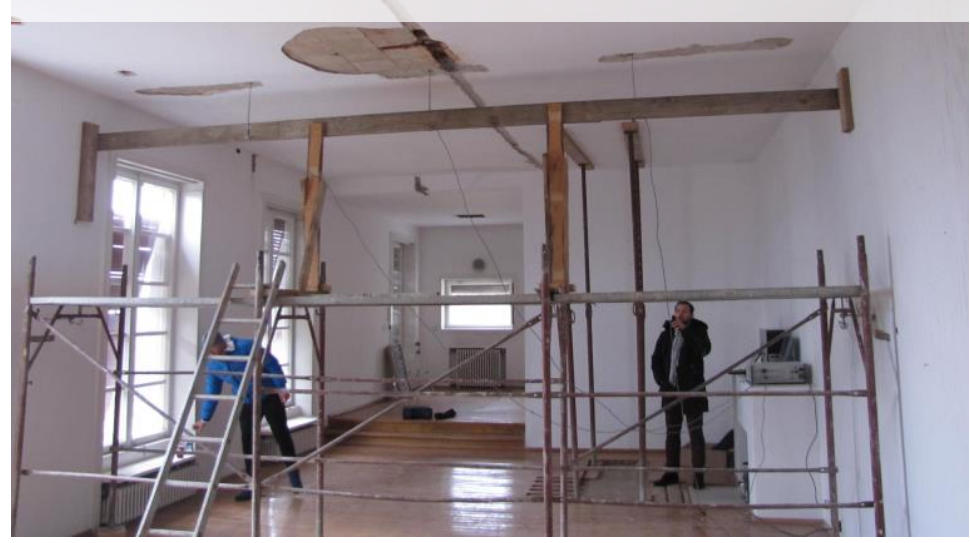

Figure 9: Slab Deflection measurement with displacement transducers

Displacement transducers, clamped to independent support, at midspan and $1 / 4$ points (Figure 9) measured and transmitted deflections to acquisition data center. Plastering was removed from 
the bottom of wider rib, for crack width monitoring. The rest of the ribs remained covered by the ceramic elements and plastering.

A structural analysis of slab strip was carried out using ATENA (Advance Tool for Engineering Nonlinear Analysis). The model contains the reinforced concrete elements, meshed with 3D FE, and non-structural elements (plastering, hollow blocks, partition wall) were considered as loads.

a.)

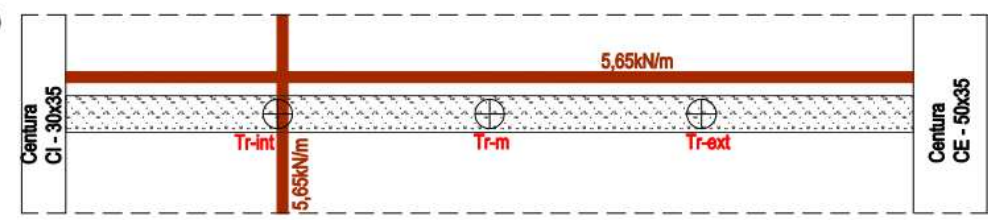

b.)

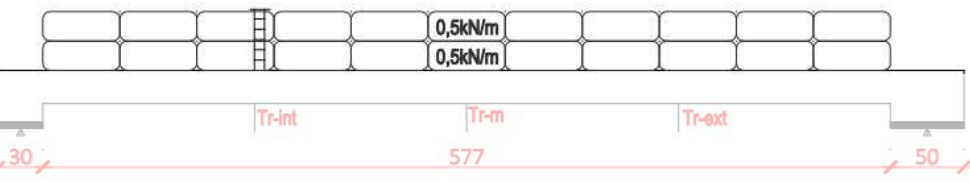

Figure 10: Slab strip scheme (a) plan and (b) section

Like the in-situ test, loads were added incrementally, considering the same step of $0.5 \mathrm{kN} / \mathrm{m}$. The maximum deflection measured at midspan is $0.27 \mathrm{~mm}$, for load step 7 , corresponding to a

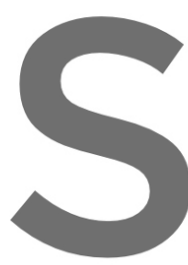
distributed load of 3 . to load sharing and stifl having different values
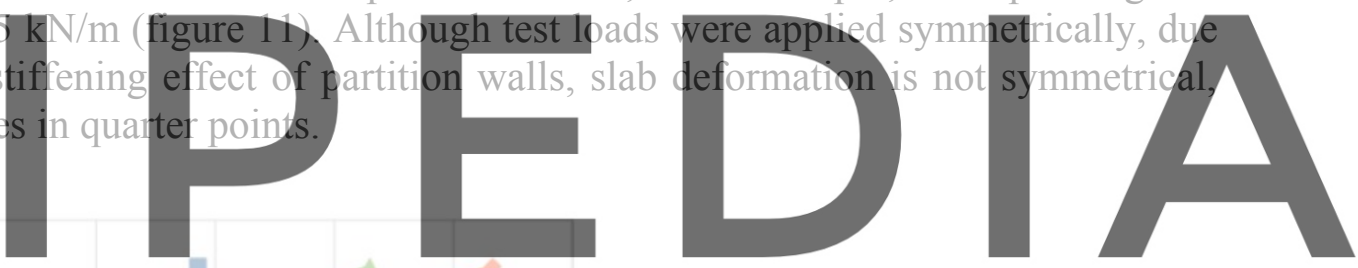

Register for free at ${ }_{5}$ https//www.scipedia.com to download the version without the watermark

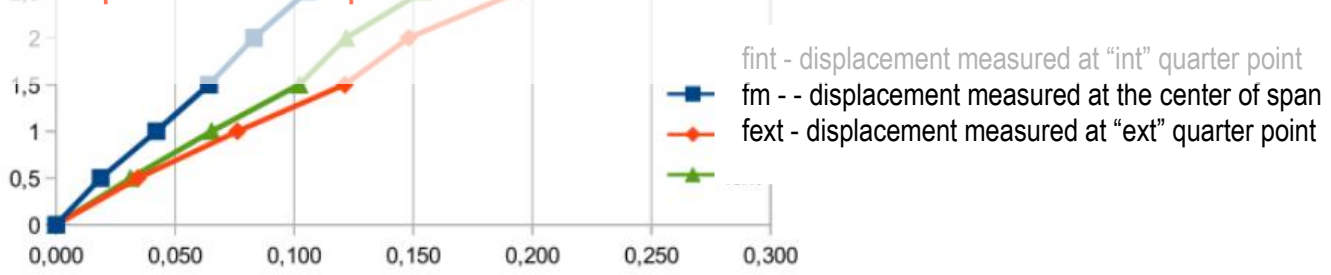

Figure 11: Measured deflection during load test [mm]

The numerical analysis results were calibrated in a conservative way, obtaining for the seven equivalent load steps almost $1 \mathrm{~mm}$ deflection. Dead load is not counted as a load step, but one can observe that it produces a $1.2 \mathrm{~mm}$ deflection (figure 12). The $27^{\text {th }}$ load step corresponds to a uniform distributed load of $13.5 \mathrm{kN} / \mathrm{m}$, which is not the ultimate load, but a satisfactory characteristic serviceability limit load, causing cracks of maximum $0.3 \mathrm{~mm}$ width. This demonstrates the initial assumption concerning construction stage deflection of slab. 


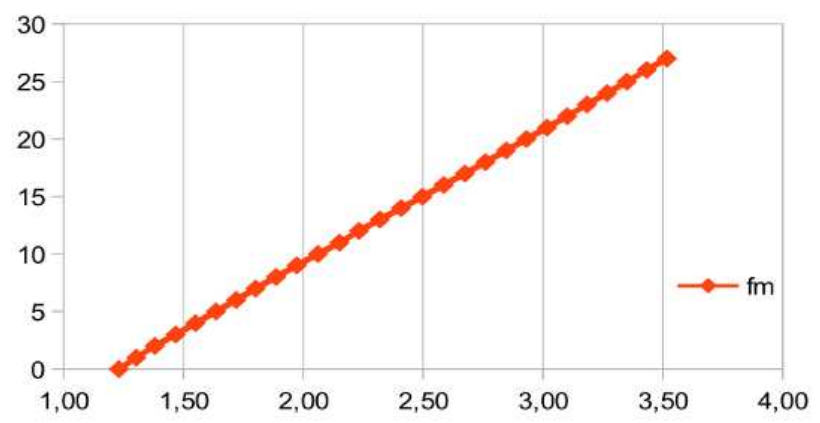

Figure 12: Calculated deflection for 27 load steps [mm]

\section{CONCLUSIONS}

The Hungarian Theatre of Cluj and Villa Tataru foreground sources of cultural heritage value in the dimensions of (a) cultural resource, involving technical, artistic, and spiritual merits; (b) live document providing outstanding technical achievements, from which societies can still learn and improve by studying and using; (c) contribution to cultural diversity and global cultural wealth [8].

The cupola of the Hungarian Theatre of Cluj, described here, is the first large-spanned reinforced concrete cupola in the world. Despite its age, the building seems to display

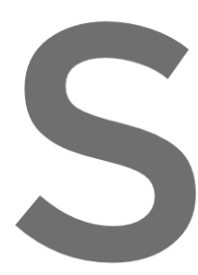
good safety. architectural dome. But Representing exceptional hist monitoring and maintenance.
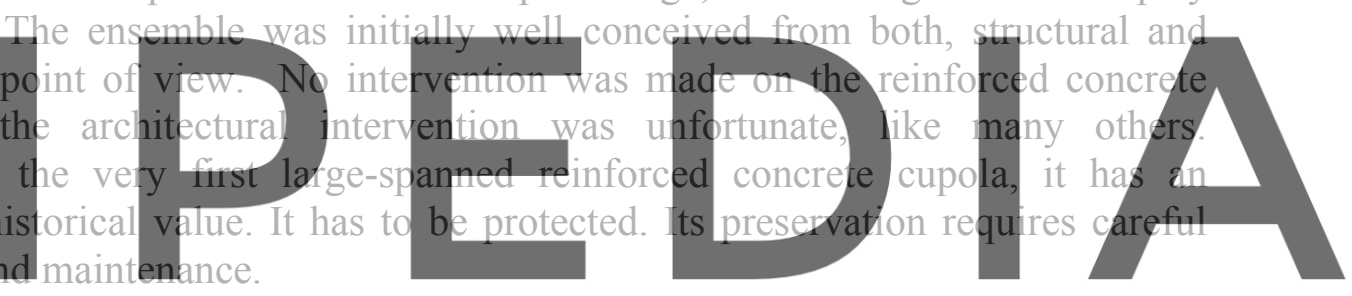

Gio Ponti's building in Cluj, Villa Tataru, reflects its creator's belief that architecture

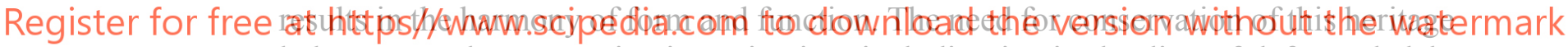

led us to conduct extensive investigation, including in-situ loading of deformed slab.

Demonstration of the ability to sustain required loads, brings into attention the additional aspect of authenticity besides the respect for original concept, materials and construction techniques, the respect for imperfections (deformations).

- $\quad$ Any intervention on a historical building has to be performed with great care. Besides the general demands concerning functionality and structural reliability, the rehabilitation process must comply with specific requirements regarding authenticity. In this sense, the rehabilitation decision and technical solution should be principlebased but, in the same time, it should be aware that every case is a unique challenge. The specialist must establish the priorities in preserving authenticity, without neglecting the functional and structural reliability of the building [3].

\section{REFERENCES}

[1] Bucur-Horváth, I. and György, M. E., Cupola as a structural element and way of architectural expression. International Symposium „Building Envelopes as Architecture's Messages", Universita degli Studi di Napoli Federico II, (2003), pp. 214-224. 
[2] Rehm, J.: The first concrete dome in Germany? Church building using modern techniques. Building Knowledge, Constructing Histories, Volume 1: Proceedings of the 6th International Congress on Construction History (6ICCH 2018), Brussels, (2018).

[3] Bucur-Horvath, I.; Popa, I.; Bulbuk, M. and Virág, J.: Historical constructions Authenticity and adaptation to the modern demands. Proceedings of the 6th International Conference Structural Analysis of Historical Constructions Preserving Safety and Significance, Bath UK, (2008), DOI: 10.1201/9781439828229.ch17

[4] Bucur-Horváth, I.: Reinforced Concrete Shell Structures in Romania as the $20^{\text {th }}$ Century Heritage, Proceedings of IASS-APCS 2012 Symposium from Spatial Structures to Shell Structures, Seoul, Korea, (2012).

[5] Lazar, E.: Una villa in Romania, Domus (magazine) no. 136, Milan (1939)

[6] International Scientific Committee on the Analysis and Restoration of Structures of Architectural Heritage (ISCARSAH): ICOMOS Charter - Principles for the analysis, conservation and structural restoration of architectural heritage (2003).

[7] ACI 318, Building code requirements for reinforced concrete structures. American Concrete Institute, (2014).

[8] Roca, P.; Lourenco, P.B. and Gaetani, A.: Historic Construction and Conservation. Materials, Systems and Damage. Routledge, (2019).

[9] Foti, D.: Shear Vulnerability of Old Historical Existing R.C. Structures. International Journal of Architectural Heritage: Conservation, Analysis, and Restoration, vol. 9, issue 4, 2015, pp. 453-467, DOI: 10.1080/15583058.2013.800920 